\title{
Identification of a gene cluster for antibacterial polyketide-derived antibiotic biosynthesis in the nystatin producer Streptomyces noursei ATCC 11455
}

\author{
Sergey Zotchev, ${ }^{1}$ Kåre Haugan, ${ }^{2}$ Olga Sekurova, ${ }^{1}$ Håvard Sletta, ${ }^{3}$ \\ Trond E. Ellingsen ${ }^{3}$ and Svein Valla ${ }^{1}$
}

Author for correspondence: Sergey Zotchev. Tel: +47 735986 79. Fax: +47 73598705 . e-mail: sergey.zotchev@chembio.ntnu.no

1 UNIGEN Center for Molecular Biology and Department of Biotechnology, NTNU, N-7489 Trondheim, Norway

2 Nord-Trondelag College, Dept of Engineering, $\mathrm{N}-7600$ Levanger, Norway

3 SINTEF Applied Chemistry, SINTEF, N-7034 Trondheim, Norway

\begin{abstract}
Streptomyces noursei ATCC 11455 produces the antifungal polyene antibiotic nystatin containing the deoxysugar moiety mycosamine. Part of the deoxythymidyl diphosphate (TDP)-glucose dehydratase gene (gdhA) known to be involved in deoxysugar biosynthesis was amplified by PCR from genomic DNA of S. noursei ATCC 11455. A gene library for $S$. noursei was made and screened with the $g d h A$ probe. Several overlapping phage clones covering about $30 \mathrm{~kb}$ of the $S$. noursei genome were physically mapped. A partial DNA sequencing analysis of this region resulted in the identification of several putative genes typical of macrolide antibiotic biosynthetic gene clusters. A gene-transfer system for $S$. noursei has been established, and gene deletion or disruption experiments within the putative biosynthetic gene cluster were performed. All of the knock-out mutants retained the ability to produce nystatin, suggesting that the identified gene cluster is not involved in biosynthesis of this antibiotic. Culture extracts from the wild-type strain and three knock-out mutants were analysed by TLC followed by a bioassay against Micrococcus luteus. Two antibacterial compounds were found to be synthesized by the wild-type strain while only one was produced by the mutants. This provided evidence for the involvement of the identified gene cluster in the biosynthesis of a presumably novel antibacterial macrolide antibiotic in S. noursei.
\end{abstract}

Keywords: Streptomyces noursei, gene cluster, macrolide antibiotic

\section{INTRODUCTION}

Filamentous soil bacteria belonging to the genus Streptomyces are widely recognized as industrially important micro-organisms because of their ability to produce antibiotics. In the past few years there has been rapid progress in genetic characterization of the biosynthetic pathways for various antibiotics produced by these

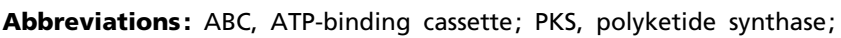
TDP, deoxythymidyl diphosphate; WT, wild-type.

The GenBank accession numbers for the sequences reported in this paper are AF071512 for ORF1, AF071513 for ORF2, AF071514 for ORF3, AF071515 for ORF4, AF071516 for ORF5, AF071517 for ORF6, AF071518 for ORF7, AF071519 for $g d h A$, AF071520 for ORF8, AF071521 for ORF9, AF071522 for ORF10 and AF071523 for ORF11.
}

organisms (Schwecke et al., 1995; Katz \& Donadio, 1995). Knowledge acquired during these studies allows one to more or less precisely predict the order of biochemical reactions leading to the synthesis of a given antibiotic. Moreover, knowledge gained through the functional analysis of antibiotic biosynthesis genes gives an opportunity to manipulate the pathways in a rational manner in order to produce novel compounds with improved properties (Hopwood, 1997).

A large number of antibiotics used in medical and veterinary care, and agriculture are of a polyketide origin. The polyketide backbone of these antibiotics is synthesized by polyketide synthase (PKS)-assisted condensation of the building units represented usually by acetyl-, propionyl- and (methyl)malonyl-CoA (Hopwood, 1997). Both the sequential manner in which 
Table 1. Bacterial strains, plasmids and phages used in this study

$\mathrm{Ap}^{\mathrm{R}}$, apramycin resistant; $\mathrm{Km}^{\mathrm{R}}$, kanamycin resistant; Thio $^{\mathrm{R}}$, thiostrepton resistant; $\mathrm{Am}^{\mathrm{R}}$, ampicillin resistant; $\mathrm{Neo}^{\mathrm{R}}$, neomycin resistant.

\begin{tabular}{|c|c|c|}
\hline $\begin{array}{l}\text { Strain, plasmid or } \\
\text { phage }\end{array}$ & Properties & Source/reference \\
\hline \multicolumn{3}{|l|}{ Bacterial strains } \\
\hline E. coli $\mathrm{DH} 5 \alpha$ & General cloning host & BRL \\
\hline E. coli ET12567 & dam-13:: Tn9 dcm-6 bsdM & MacNeil et al. (1992) \\
\hline M. luteus ATCC 10240 & Wild-type & ATCC $†$ \\
\hline S. lividans 1326 & Wild-type & H. Schrempf $\neq$ \\
\hline S. noursei ATCC 11455 & Wild-type, nystatin producer & ATCC + \\
\hline \multicolumn{3}{|l|}{ Plasmids } \\
\hline pGEM3Zf $(-)$ & ColE1 replicon, $\mathrm{Ap}^{\mathrm{R}}, 3 \cdot 2 \mathrm{~kb}$ & Promega \\
\hline pUC4K & ColE1 replicon, $\mathrm{Km}^{\mathrm{R}} \mathrm{Ap}^{\mathrm{R}}, 3.9 \mathrm{~kb}$ & Pharmacia \\
\hline pUZ8002 & $\mathrm{RK} 2$ derivative, $\mathrm{Km}^{\mathrm{R}} \mathrm{Tc}^{\mathrm{R}}$ & D. H. Figurski\ \\
\hline pGM11 & pSG5 replicon, $\mathrm{Neo}^{\mathrm{R}}, 5 \cdot 3 \mathrm{~kb}$ & $\begin{array}{l}\text { Wohlleben \& Muth } \\
\text { (1993) }\end{array}$ \\
\hline pWHM3 & ColE1 + pIJ101 replicons, Thio ${ }^{\mathrm{R}}, 7 \cdot 2 \mathrm{~kb}$ & Vara et al. (1989) \\
\hline pHZ1351 & $\begin{array}{l}\text { ColE1+ replicon from Streptomyces sp. } \\
\text { FR-005, Thio }{ }^{R}, 8 \cdot 3 \mathrm{~kb}\end{array}$ & Z. Deng $\|$ \\
\hline pKC1218 & $\begin{array}{l}\text { ColE1+SCP2\% replicon, oriT, } \mathrm{Am}^{\mathrm{R}} \text {, } \\
5 \cdot 8 \mathrm{~kb}\end{array}$ & Bierman et al. (1992) \\
\hline pSET152 & $\begin{array}{l}\text { ColE1 replicon }+\phi \mathrm{C} 31 \mathrm{int} \text {, oriT, } \mathrm{Am}^{\mathrm{R}} \text {, } \\
5 \cdot 5 \mathrm{~kb}\end{array}$ & Bierman et al. (1992) \\
\hline pSOK101 & $\begin{array}{l}\text { pWHM3 derivative with } 3 \cdot 1 \mathrm{~kb} \\
\text { BamHI-SphI fragment replaced with } \\
3 \cdot 0 \mathrm{~kb} \text { BamHI-SphI fragment from } \\
\text { pSET152 containing ColE1, oriT and } \\
\mathrm{Am}^{\mathrm{R}}, 7 \cdot 1 \mathrm{~kb}\end{array}$ & This work \\
\hline pSOK201 & $\begin{array}{l}\text { pGM11 derivative with } 1 \cdot 2 \mathrm{~kb} \\
\text { EcoRI-HindIII fragment replaced with } \\
3 \cdot 0 \mathrm{~kb} \text { EcoRI-HindIII fragment from } \\
\text { pSOK101 containing ColE1, oriT and } \\
\mathrm{Am}^{\mathrm{R}}, 7 \cdot 1 \mathrm{~kb}\end{array}$ & This work \\
\hline pCHZ101 & $\begin{array}{l}\text { pHZ1351 derivative with } 4 \cdot 0 \mathrm{~kb} \\
\text { Bam HI-HindIII fragment replaced with } \\
3 \cdot 0 \mathrm{~kb} \text { Bam HI-HindIII fragment from } \\
\text { pSOK101 containing ColE1, oriT and } \\
\mathrm{Am}^{\mathrm{R}}, 7 \cdot 3 \mathrm{~kb}\end{array}$ & This work \\
\hline pGEM-RN4 & $\begin{array}{l}1.6 \mathrm{~kb} \text { EcoRI-Bam HI fragment from } \\
\mathrm{KH} 11 \text { and } 1.35 \mathrm{~kb} \text { BamHI-SalI fragment } \\
\text { from KH12 cloned into pGEM3Zf }(-) \text {, } \\
\mathrm{Ap}^{\mathrm{R}}, 6.15 \mathrm{~kb}\end{array}$ & This work \\
\hline pRN4 & $\begin{array}{l}2.95 \mathrm{~kb} \text { EcoRI-HindIII fragment from } \\
\text { pGEM-RN4 joined to the } 3.0 \mathrm{~kb} \\
\text { EcoRI-HindIII fragment from pSOK101 } \\
\text { containing ColE1, Am }{ }^{\mathrm{R}} \text { and oriT, } \\
5.95 \mathrm{~kb}\end{array}$ & This work \\
\hline pRN8 & $\begin{array}{l}1.4 \mathrm{~kb} \text { Bam HI-EcoRI fragment from } \\
\mathrm{KH} 12 \text { joined to the } 1 \cdot 3 \mathrm{~kb} \mathrm{Km^{ \textrm {R } }} \text { EcoRI } \\
\text { fragment from pUC4K, the } 1.4 \mathrm{~kb} \\
\text { EcoRI-SphI fragment from KH12 and } \\
\text { the } 3.0 \mathrm{~kb} \text { Bam } \mathrm{HI}-S p h \mathrm{I} \text { fragment from } \\
\text { pSET152 containing ColE1, Am }{ }^{\mathrm{R}} \text {, oriT, } \\
7 \cdot 3 \mathrm{~kb}\end{array}$ & This work \\
\hline
\end{tabular}


Table 1. (cont.)

\begin{tabular}{|c|c|c|}
\hline $\begin{array}{l}\text { Strain, plasmid or } \\
\text { phage }\end{array}$ & Properties & Source/reference \\
\hline pGEM-ND2 & $\begin{array}{l}1.3 \mathrm{kbBamHI}-E c o \text { RI fragment from KH} 16 \\
\text { cloned into pGEM } 3 \mathrm{Zf}(-), \mathrm{Ap}^{\mathrm{R}}, 4.5 \mathrm{~kb}\end{array}$ & This work \\
\hline pND2 & $\begin{array}{l}1 \cdot 3 \mathrm{~kb} \text { HindIII-EcoRI fragment from } \\
\text { pGEM-ND2 joined to } 3 \cdot 0 \mathrm{~kb} \\
\text { HindIII-EcoRI fragment from pSOK101 } \\
\text { containing ColE1, } \mathrm{Am}^{\mathrm{R}} \text {, oriT, } 4 \cdot 3 \mathrm{~kb}\end{array}$ & This work \\
\hline \multicolumn{3}{|l|}{ Phages } \\
\hline DASHII & Bacteriophage $\lambda$ vector & Stratagene \\
\hline
\end{tabular}

† American Type Culture Collection, Manassas, VA, USA.

‡FB, Biologie/Chimie, University of Osnabrück, D-49069 Osnabrück, Germany.

\$Dept of Microbiology, College of Physicians and Surgeons, Columbia Univeristy, NY 10032, USA

|| Huazhong Agricultural University, Wuhan, China.

the backbone is assembled and the fact that specific domains within a PKS are responsible for a given biosynthetic step provides an excellent opportunity for protein engineering. Indeed, several research groups have reported successful manipulations of PKS genes which resulted in biosynthesis of new compounds (for example, Kuhstoss et al., 1996; Ruan et al., 1997). However, the polyketide backbone by itself usually has little, if any, biological activity. Modifications of this backbone by means of hydroxylation, methylation, acylation and glycosylation are usually required for achieving full potency, and the genes providing these activities are often found in the proximity of the PKS genes (Katz \& Donadio, 1995). This fact further expands the possibilities for manipulations of the biosynthetic pathways, potentially leading to overproducing strains or new antibiotics (Sezonov et al., 1997; Solenberg et al., 1997).

We have initiated molecular genetic studies on Streptomyces noursei ATCC 11455, the producer of the antifungal polyene antibiotic nystatin. The latter is currently being used for the treatment of many fungal infections in humans. The structure of nystatin predicts the involvement of type I (modular) PKS enzymes in biosynthesis of its polyketide backbone, while a mycosamine moiety attached to the aglycone implies involvement of deoxysugar biosynthesis genes. Using a PCR-derived probe for the deoxythymidyl diphosphate (TDP)-glucose dehydratase gene, we have identified part of the gene cluster apparently governing the biosynthesis of a macrolide antibiotic. Gene disruption and replacement experiments showed that this gene cluster is not required for nystatin biosynthesis, but that it governs the synthesis of an antibacterial agent in $S$. noursei ATCC 11455.

\section{METHODS}

Bacterial strains, plasmids and phages. Bacterial strains, plasmids and phages used in this study are listed in Table 1 except for plasmids pKH10, pKH11, pKH12, pKH14, pKH15, pKH16 and pKH17. These plasmids were constructed by cloning the corresponding EcoRI KH fragments depicted in Fig. 1(a) into the EcoRI site of pGEM3Zf $(-)$.

Media, growth conditions and transformation procedures. $S$. noursei ATCC 11455 and its mutants were grown on solid ISP2 medium (Difco) and in liquid TSB medium (Sigma). For preparation of protoplasts, cultures were grown at $30^{\circ} \mathrm{C}$ for $40 \mathrm{~h}$ in TSB medium supplemented with $1.5 \%$ glycine. $S$. nourse $i$ protoplasts were prepared and regenerated according to Hopwood et al. (1985) except that P medium contained $20 \%$ sucrose and regeneration medium R5 contained $15 \%$ sucrose. Streptomyces lividans 1326 protoplasts were obtained and transformed as described by Hopwood et al. (1985). Intergeneric conjugation from Escherichia coli ET12567(pUZ8002) into Streptomyces strains was done as described by Flett et al. (1997). E. coli strains were grown and transformed as described by Sambrook et al. (1989) except for E. coli ET12567(pUZ8002), which was maintained on media containing $20 \mu \mathrm{g}$ chloramphenicol $\mathrm{ml}^{-1}$ and $50 \mu \mathrm{g}$ kanamycin $\mathrm{ml}^{-1}$. Micrococcus luteus ATCC 10240 was maintained essentially as E. coli strains except that the incubation temperature was $35^{\circ} \mathrm{C}$.

Molecular genetic techniques. Plasmid, phage and total DNA preparations, endonuclease digestions, ligations and fractionation were performed as described previously (Sambrook et al., 1989; Hopwood et al., 1985). Modification of plasmid DNA in vitro was done according to Matsushima \& Baltz (1994). DNA fragments were isolated from agarose gels using the Qiagen QIAEX kit, labelled by the use of the HighPrime kit from Boehringer Mannheim, and used for Southern blot analysis. PCR amplification of the $g d h$ fragment was done according to Decker et al. (1996). DNA sequencing reactions were performed with a DNA sequencing kit from Applied Biosystems and analysed with an automated DNA sequencer from the same supplier. DNA sequences were analysed using the GCG program package (Devereux et al., 1984) and deposited in GenBank.

Analysis of secondary metabolites. For nystatin production, S. noursei strains were grown for $120 \mathrm{~h}$ in $50 \mathrm{ml} \mathrm{SAO-23}$ medium (g per l: glucose, $45 ; \mathrm{NH}_{4} \mathrm{NO}_{3}, 2 \cdot 5$; corn meal, 3 ; $\left.\mathrm{MgSO}_{4} .7 \mathrm{H}_{2} \mathrm{O}, 0 \cdot 4 ; \mathrm{KH}_{2} \mathrm{PO}_{4}, 0 \cdot 2 ; \mathrm{CaCO}_{3}, 5\right)$ in shake flasks at 
(a)

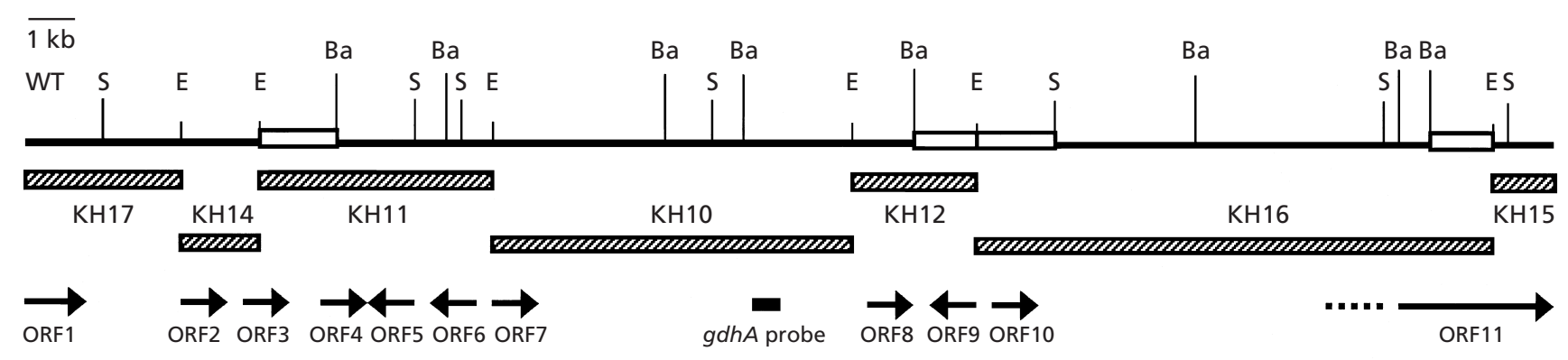

(b)

RN413

deletion

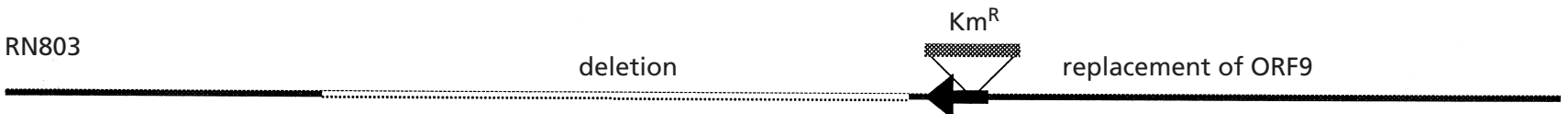

ND21

ORF11 disruption

Fig. 1. Putative macrolide antibiotic biosynthesis gene cluster in S. noursei ATCC 11455. (a) Partial physical and genetic map. Shaded boxes represent fragments used for subcloning and DNA sequencing; $E=E c o R I, B a=B a m H I, S=S p h$. White boxes indicate DNA fragments used in gene inactivation experiments (see text and Table 1 for details). (b) Genetic maps of the mutants constructed via gene replacement and disruption.

$28{ }^{\circ} \mathrm{C}(220$ r.p.m.). Cells were then pelleted and extracted with DMSO, and extracts analysed by HPLC. For production of antibacterial compounds, S. nourse $i$ was grown for $120 \mathrm{~h}$ in $50 \mathrm{ml} \mathrm{MP1}$ medium (g per 1: glucose, 40; yeast extract, 1.5; $\left.\mathrm{NH}_{4} \mathrm{NO}_{3}, 2.5 ; \mathrm{MgSO}_{4} .7 \mathrm{H}_{2} \mathrm{O}, 0.5 ; \mathrm{KH}_{2} \mathrm{PO}_{4}, 0.5 ; \mathrm{CaCO}_{3}, 3\right)$ in shake flasks at $28^{\circ} \mathrm{C}$ (220 r.p.m.). Culture supernatants were then extracted with equal volumes of ethyl acetate, and extracts were evaporated under vacuum. The pellets were dissolved in small amounts of ethyl acetate and subjected to TLC analysis. TLC plates (Merck) were developed in ethyl acetate/methanol/water $(100: 2 \cdot 5: 1$, by vol.). For antibacterial agent bioassay, TLC plates were placed for $30 \mathrm{~min}$ on the surface of LB agar plates inoculated with $M$. luteus ATCC 10240. The agar plates were then incubated for $16 \mathrm{~h}$ at $35^{\circ} \mathrm{C}$ and screened visually for growth-inhibition zones.

\section{RESULTS}

\section{Identification of a macrolide antibiotic biosynthesis gene cluster in S. noursei ATCC 11455}

Several groups have reported the cloning of gene clusters for biosynthesis of antibiotics containing a deoxysugar moiety using a probe for the TDP-glucose dehydratase $(g d h)$ gene, which governs one of the initial steps in deoxysugar formation (Liu \& Thorson, 1994). Since the nystatin molecule contains the deoxysugar mycosamine, we decided to use a similar approach to identify the nystatin biosynthesis gene cluster. Part of a presumptive $g d h$ gene was amplified from the $S$. noursei chromosome by PCR with primers designed by Decker et al. (1996). DNA sequence analysis of the $550 \mathrm{bp}$ PCR product designated $g d h A$ showed that it encodes a peptide with $41.6 \%$ identity to the RfbB TDP-glucose dehydratase from Xanthomonas campestris (Table 2). Hybridization of the labelled $g d h A$ probe under high stringency conditions with $S$. noursei chromosomal DNA digested with several restriction enzymes showed the presence of one copy of $g d h A$ in the genome (data not shown). A $S$. noursei gene library was then prepared in the bacteriophage $\lambda$ vector DASHII. Screening of this library with the $g d h A$ probe allowed the isolation of several overlapping phage clones which were then aligned according to their physical maps and hybridization with $g d h A$. Next, an EcoRI and some BamHI DNA fragments from the identified region were subcloned in the pGEM3Zf $(-)$ vector and subjected to partial DNA sequence analysis. This analysis revealed several putative genes typical of those governing the biosynthesis of polyketide-derived antibiotics (Table 2). In particular, 
Table 2. Genes identified within the putative macrolide antibiotic biosynthesis gene cluster from S. noursei ATCC 11455 by partial DNA sequencing and comparative analysis

\begin{tabular}{|lclc|}
\hline ORF & $\begin{array}{c}\text { Partial } \\
\text { sequence }\end{array}$ & Match in the databases & $\begin{array}{c}\text { Identity } \\
(\%)\end{array}$ \\
\hline 1 & 133 aa & OleB ABC transporter (Olano et al., 1995), aa 338-467 & $62 \cdot 4$ \\
2 & 157 aa & Streptomycin 6-kinase (Vogtli \& Hutter, 1987), aa 250-309 & $35 \cdot 5$ \\
3 & 170 aa & EryBV glycosyltransferase (Gaisser et al., 1997), aa 28-189 & $52 \cdot 9$ \\
4 & 117 aa & Putative transposase (Kaluza et al., 1985), aa 257-354 & $27 \cdot 1$ \\
5 & 144 aa & EryF hydroxylase (Weber et al., 1991), aa 306-407 & $57 \cdot 1$ \\
6 & 174 aa & MycF O-methyltransferase (Inouye et al., 1994), aa 70-223 & $71 \cdot 2$ \\
7 & 115 aa & SnoY (Ylihonko et al., 1996), aa 1-114 & $28 \cdot 2$ \\
$g d h A$ & 186 aa & RfbB TDP-glucose dehydratase (Koplin et al., 1993), aa 9-197 & $41 \cdot 6$ \\
8 & 187 aa & Deoxyhexose reductase (Gaisser et al., 1997), aa 9-162 & $48 \cdot 7$ \\
9 & 181 aa & TDP-glucose dehydratase (Lombo et al., 1997), aa 6-172 & $67 \cdot 2$ \\
10 & 110 aa & TDP-glucose synthase (Tsukioka et al., 1997), aa 1-110 & $60 \cdot 9$ \\
11 & 181 aa & EryA2 PKS (Donadio et al., 1991), aa 120-300 & $75 \cdot 7$ \\
\hline
\end{tabular}

genes presumably encoding proteins homologous to an ABC (ATP-binding cassette) transporter (ORF1), glycosyltransferase (ORF3), putative transposase (ORF4), P450 hydroxylase (ORF5), O-methyltransferase (ORF6), deoxyhexose reductase (ORF8), a second TDPglucose dehydratase (ORF9), TDP-glucose synthase (ORF10) and type I PKS (ORF11) have been identified (see Fig. 1a for their locations).

\section{Development of a gene-transfer system for $S$. noursei ATCC 11455}

To specifically inactivate the genes within the identified cluster, a gene transfer system for $S$. noursei had to be established. Initial studies showed that the organism is resistant to high concentrations of thiostrepton

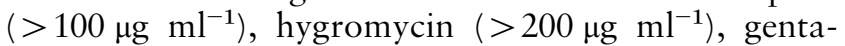
micin $\left(>50 \mu \mathrm{g} \mathrm{ml}^{-1}\right)$ and erythromycin $\left(>100 \mu \mathrm{g} \mathrm{ml}^{-1}\right)$. $S$. noursei plated on agar media supplemented with neomycin $\left(>50 \mu \mathrm{g} \mathrm{ml}^{-1}\right)$, kanamycin $\left(>50 \mu \mathrm{g} \mathrm{ml}^{-1}\right)$ or viomycin $\left(>50 \mu \mathrm{g} \mathrm{ml}^{-1}\right)$ consistently gave some background growth. However, S. noursei was sensitive to apramycin at concentrations $>30 \mu \mathrm{g} \mathrm{ml}^{-1}$ so this antibiotic was chosen for selection of transformants.

Although a method for efficient protoplast formation and regeneration for $S$. noursei ATCC 11455 was established (see Methods), all our attempts to achieve $S$. noursei protoplast transformation with vectors pKC1218 and pSET152 using both standard and modified techniques failed. To extend the choice of vectors, the new plasmids pSOK101 (pIJ101 replicon), pSOK201 (pSG5 replicon) and pCHZ101 (pHZ1351 replicon) were constructed (see Fig. 2 and Table 1). However, transformation of $S$. noursei protoplasts with the above vectors failed to give any transformants. All five plasmids used in these transformation experiments contain the origin of transfer, oriT, from plasmid RP4 allowing mobilization of the construct during conjugation from an appropriate E. coli strain into Streptomyces sp. (Mazodier et al., 1989). The plasmids could easily be introduced into S. lividans 1326 via both protoplast transformation and conjugation from $E$. coli ET12567(pUZ8002). Conjugation experiments with S. noursei (Table 3) using pSOK101, pKC1218 and pCHZ101 were unsuccessful. For pSOK201, a relatively high number of small apramycin-resistant colonies appeared on the conjugation plates. However, these putative transconjugants stopped growing after 3-4 d incubation and did not develop into normal colonies. Attempts to transfer these small colonies to fresh selective media resulted in slow-growing and poorly sporulating colonies from which no plasmid DNA could be isolated. About 1-2 colonies per plate were isolated when plasmid pSET152 carrying the site-specific integration system from streptomycete phage $\phi \mathrm{C} 31$ was used for conjugation. Southern blot analysis of two such S. noursei (pSET152) clones with labelled pSET152 DNA indicated integration of the plasmid into a specific site on the chromosome (data not shown).

\section{Gene replacements and disruption within the identified gene cluster}

The successful introduction of pSET152 into S. noursei ATCC 11455 provided evidence for intergeneric conjugation being the only tool for gene transfer into this organism. To test the possible involvement of the ORFs within the identified gene cluster in nystatin biosynthesis, gene-inactivation experiments were carried out. For this purpose, the suicide vector pRN4 was constructed by cloning, in the original orientation, a $1.6 \mathrm{~kb}$ EcoRI-BamHI fragment from pKH11 and a $1.35 \mathrm{~kb}$ BamHI-SalI fragment from pKH12 (SalI site not shown on the map) into a suicide vector carrying oriT and an apramycin-resistance gene (see Fig. 1a and Table 1). S. noursei ATCC 11455 transconjugants carrying pRN4 integrated into the chromosome via a singlecrossover event were obtained at a frequency four times higher than that found for the site-specific integration of pSET152. One of the transconjugants was allowed three 

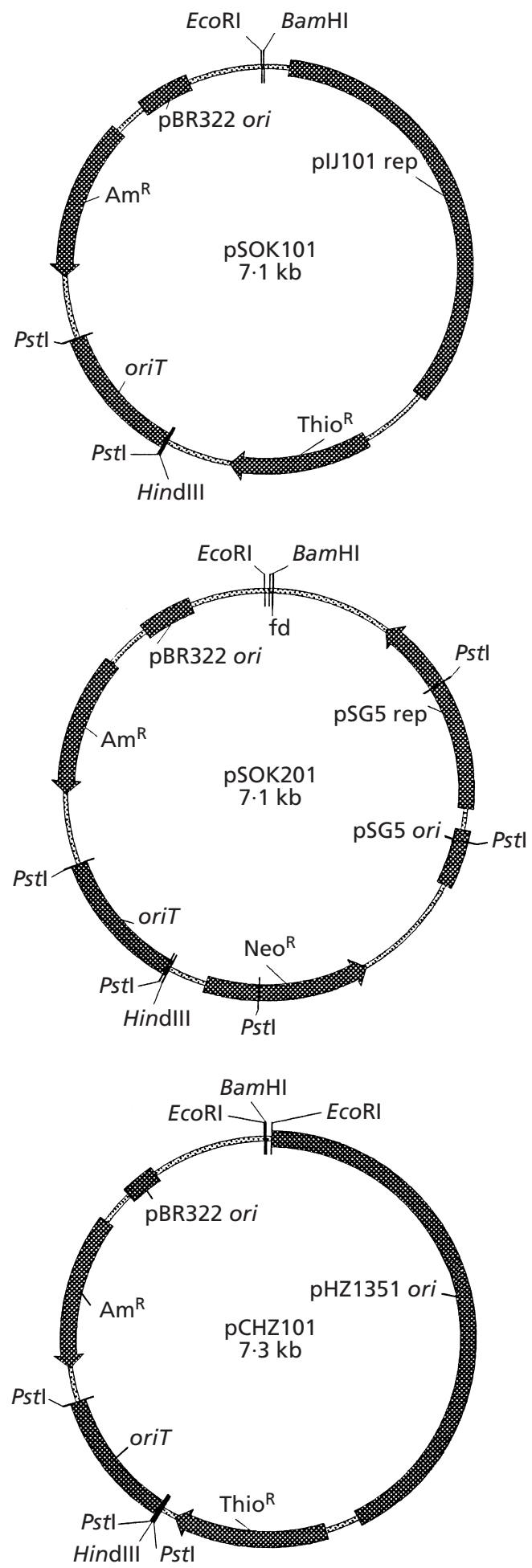

Fig. 2. New E. coli-Streptomyces bifunctional cloning vectors capable of intergeneric conjugation. BamHI, EcoRI and HindIII sites in all vectors are unique. For details on construction see Table 1.

rounds of sporulation on ISP2 agar without antibiotic selection and its progeny were screened for loss of the apramycin-resistance marker. Four such clones were
Table 3. Gene transfer to S. noursei ATCC 11455 via conjugation from E. coli ET12567(pUZ8002).

\begin{tabular}{|c|c|c|c|}
\hline Plasmid & Replicon & $\begin{array}{l}\text { Efficiency per } \\
\text { recipient }\end{array}$ & Notes \\
\hline pSOK101 & pIJ101 & $<3 \times 10^{-8}$ & \\
\hline pKC1218 & $\mathrm{SCP} 2 *$ & $<3 \times 10^{-8}$ & \\
\hline pSOK201 & pSG5 & $6 \times 10^{-5}$ & $\begin{array}{l}\text { Colonies are sick and } \\
\text { grow poorly when } \\
\text { retransferred on } \\
\text { selective medium }\end{array}$ \\
\hline pCHZ101 & pHZ1351 & $<3 \times 10^{-8}$ & \\
\hline pSET152 & $\phi \mathrm{C} 31 \mathrm{int}$ & $5 \times 10^{-8}$ & Site-specific integration \\
\hline
\end{tabular}

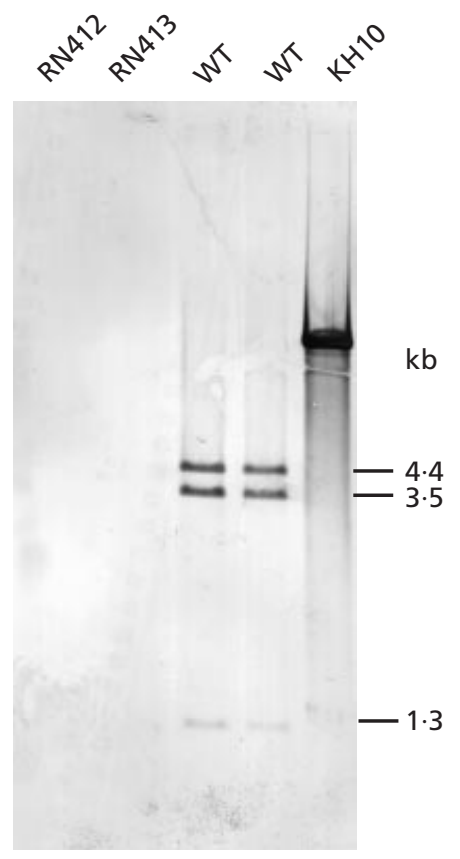

Fig. 3. Southern blot analysis of the BamHI-digested total DNA isolated from S. noursei ATCC 11455 (WT), RN412 and RN413 with labelled $\mathrm{KH} 10$ probe. Hybridizing fragments present in WT and absent from RN412 and RN413 are indicated with the arrows. Intact $\mathrm{KH} 10$ fragment was used as a positive control.

selected and two of them, RN412 and RN413, were shown by hybridization of the labelled KH10 DNA fragment with their total DNA to contain the desired deletion (Fig. 3). As shown in Fig. 1(b), the above mutants have deletions of approximately $10.6 \mathrm{~kb}$, affecting ORF5, ORF6, ORF7, gdhA and ORF8.

ORF9, presumably encoding the second TDP-glucose dehydratase, was inactivated by gene replacement with pRN8. The latter was made by cloning the $1.4 \mathrm{~kb}$ BamHI-EcoRI fragment from pKH12, a $1.3 \mathrm{~kb}$ EcoRI kanamycin-resistance fragment and a $1.4 \mathrm{~kb} E c o \mathrm{RI}-S p h \mathrm{I}$ fragment from pKH16 in a mobilizable suicide vector (see Fig. 1a and Table 1). The ORF9 gene replacement procedure was followed as above except that it was 


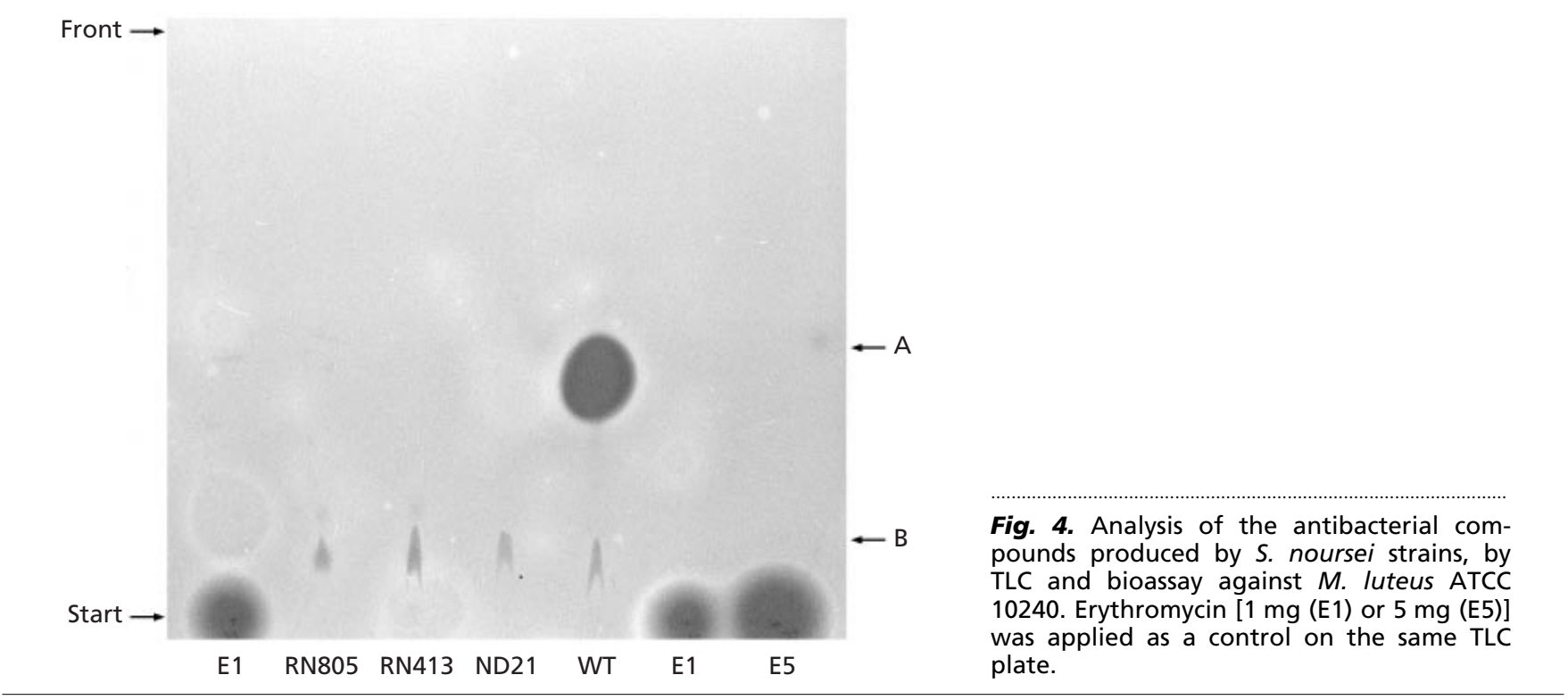

performed in $S$. noursei strain RN413. In three recombinant strains, designated RN803, RN805 and RN807, ORF9 replacement was confirmed by Southern blot analysis (data not shown).

Finally, inactivation of ORF11, presumably encoding a type I PKS enzyme in $S$. noursei ATCC 11455 , was made by gene disruption with pND2. pND2 was constructed by cloning the internal $1.3 \mathrm{~kb} B a m \mathrm{HI}-E c o \mathrm{RI}$ fragment of ORF11 from KH16 into a mobilizable suicide vector (see Fig. 1a and Table 1). Integration of pND2 into the chromosome via a single crossover upon intergeneric conjugation resulted in strains ND21 and ND22. The integration of pND2 in these strains was also confirmed by Southern blot analysis of their total DNA (data not shown). The genotypes of all the recombinant strains constructed are presented in Fig. 1(b).

\section{Analysis of secondary metabolites produced by the wild-type strain and knock-out mutants}

S. noursei strains RN413, RN803 and ND21 were tested for nystatin production by shake flask experiments in the semi-defined medium SAO-23. All the mutants constructed produced nystatin in amounts similar to the wild-type (WT) strain ATCC 11455. Thus, it was concluded that the identified gene cluster is not involved in the biosynthesis of nystatin. From the information we had on the putative genes within the cluster, it was logical to assume that the cluster governs the biosynthesis of some macrolide antibiotic which is exported out of the cell (presence of gene for a putative $A B C$ transporter). Thus, we focused our attempts on isolation of this unknown antibiotic. The shake flask fermentations were carried out with the mutant and the WT strains in the semi-defined medium MP1. Ethyl acetate extracts of the supernatants from $120 \mathrm{~h}$ cultures were analysed by TLC followed by a bioassay against M. luteus ATCC 10240. A large growth inhibition zone corresponding to the TLC spot with $R_{F} 0.44$ (A) was observed in the case of the WT strain (Fig. 4), while none of the mutants displayed a similar inhibition zone. We thus concluded that this zone corresponds to the compound (A) synthesized by the products of the putative genes within the identified gene cluster. In addition, the extracts from all strains contained another compound with antibacterial activity, as small inhibition zones corresponding to TLC spots with $R_{F} 0 \cdot 12$ (B) were also observed (Fig. 4). Thus, the WT strain is capable of producing at least two antibacterial compounds, $\mathrm{A}$ and $\mathrm{B}$, while the mutants fail to produce $\mathrm{A}$ due to the specific mutations within its biosynthetic gene cluster.

\section{DISCUSSION}

Using a PCR-amplified DNA probe for the putative TDP-glucose dehydratase gene we have isolated a $30 \mathrm{~kb}$ genomic region from $S$. noursei ATCC 11455, the producer of the antifungal antibiotic nystatin. A partial DNA sequencing analysis within the cloned segment revealed the presence of several ORFs presumably encoding homologues of the proteins involved in biosynthesis of, and resistance to, antibiotics in different streptomycetes. Establishment of a gene-transfer system for $S$. noursei allowed gene-inactivation experiments, which demonstrated that the identified gene cluster is not responsible for nystatin biosynthesis. However, by comparing the biological activities in culture supernatants of the WT strain and its constructed mutants, we were able to demonstrate the involvement of this gene cluster in the biosynthesis of a presumably novel antibacterial compound.

We speculate that this new compound is a macrolide antibiotic on the basis of the observed absence of the specific antibacterial activity in the mutant ND21 with disrupted ORF11, presumably encoding a type I PKS. 
Sequence comparisons also suggest that the polyketide backbone of this compound might be modified by the means of hydroxylation (ORF5) and O-methylation (ORF6) during antibiotic synthesis. Five of the ORFs found within the cluster appear to be responsible for synthesis ( $g d h A$, ORF8, ORF9 and ORF10) and attachment (ORF3) of deoxysugar(s) to the macrolide antibiotic precursor(s). It thus seems likely that at least one deoxysugar is attached to the polyketide moiety. Interestingly, two putative genes, $g d h A$ and ORF9, both presumably encoding Gdh, are present in this cluster. It is possible that the two putative $g d h$ genes are responsible for synthesis of two different deoxysugars, even though to our knowledge there is no precedent for finding two $g d h$ genes within one cluster. Alternatively, one of the identified $g d h$ genes may not encode a true dehydratase, but another as yet undescribed enzyme involved in deoxysugar formation. The modifications of the polyketide moiety seem to be crucial for the antibiotic activity, as a deletion affecting ORFs 5-8 and $g d h A$ abolishes the specific antibacterial activity in mutant RN413. However, due to the limited DNA sequence data, we cannot exclude the possibility of a regulatory gene being affected by the deletion.

The two ORFs found within the cluster might be responsible for the resistance of $S$. noursei to the macrolide antibiotic identified. ORF1 seems to encode an $\mathrm{ABC}$ transporter homologous to the Streptomyces antibioticus OleB ATP-binding protein involved in the efflux of oleandomycin from the producing organism (Olano et al., 1995). Another putative resistance gene might be represented by ORF2, which displays similarity to the Streptomyces glaucescens streptomycin 6-kinase responsible for the inactivation of streptomycin by means of its phosphorylation (Vogtli \& Hutter, 1987).

Finally, the putative ORF4 product resembles transposases from the Rhizobium japonicum insertion element (Kaluza et al., 1985) and insertion elements from some other bacteria. There is at least one other reported case of an insertion element being present in the antibiotic biosynthesis gene cluster; IS1136 was found between the PKS-encoding genes in the erythromycin biosynthesis gene cluster of Saccharopolyspora erythraea (Donadio \& Staver, 1993).

So far, the production of two antifungal antibiotics of polyketide origin by $S$. noursei, cycloheximide and nystatin, had been documented (Roszkowski et al., 1972). Although Brown \& Hazen (1953) reported isolation of the antibacterial antibiotic phalamycin from a spontaneously obtained morphological variant of $S$. noursei, this strain was apparently a nystatin nonproducer and phalamycin was not produced by the wildtype $S$. noursei. Thus, it is not clear whether the phalamycin-producing strain was really $S$. noursei. We therefore suggest that the antibacterial compound identified in this study and the putative genes for its biosynthesis are novel. Further characterization of this antibiotic aimed at its purification, and elucidation of its chemical structure and potency, is under way.

\section{ACKNOWLEDGEMENTS}

We wish to thank M. Bibb, Z. Deng, D. H. Figurski, C. R. Hutchinson, D. MacNeil, G. Muth and H. Schrempf for supplying us with bacterial strains and vectors. We also express gratitude to the people from Streptomyces research groups at the John Innes Institute, especially to M. Bibb and M. Paget, for their help in developing the gene-transfer system and useful discussions. We thank E. Fjærvik and A. Strøm for their participation in the discussions in the course of this work. This study was supported by a grant from the Norwegian Research Council.

\section{REFERENCES}

Bierman, M., Logan, R., O'Brien, K., Seno, E. T., Rao, R. N. \& Schoner, B. E. (1992). Plasmid cloning vectors for the conjugal transfer of DNA from Escherichia coli to Streptomyces spp. Gene 116, 43-49.

Brown, R. \& Hazen, E. L. (1953). Phalamycin, an antibacterial agent produced by a Streptomyces noursei variant. Antimicrob Agents Chemother 8, 818-821.

Decker, H., Gaisser, S., Pelzer, S., Schneider, P., Westrich, L., Wohlleben, W. \& Bechthold, A. (1996). A general approach for cloning and characterizing dNTP-glucose dehydratase genes from actinomycetes. FEMS Microbiol Lett 141, 195-201.

Devereux, J., Haeberli, P. \& Smithies, O. (1984). A comprehensive set of sequence analysis programs for the VAX. Nucleic Acids Res 12, 387-395.

Donadio, S. \& Staver, M. J. (1993). IS1136, an insertion element in the erythromycin gene cluster of Saccharopolyspora erythraea. Gene 126, 147-151.

Donadio, S., Staver, M. J., McAlpine, J. B., Swanson, S. J. \& Katz, L. (1991). Modular organization of genes required for complex polyketide biosynthesis. Science 252, 675-679.

Flett, F., Mersinias, V. \& Smith, C. P. (1997). High efficiency conjugal transfer of plasmid DNA from Escherichia coli to methyl DNA-restricting streptomycetes. FEMS Microbiol Lett 155, 223-229.

Gaisser, S., Bohm, G. A., Cortes, J. \& Leadlay, P. F. (1997). Analysis of seven genes from the eryAI-eryK region of the erythromycin biosynthetic gene cluster in Saccharopolyspora erythraea. Mol Gen Genet 256, 239-251.

Hopwood, D. A. (1997). Genetic contributions to understanding polyketide synthases. Chem Rev 97, 2465-2497.

Hopwood, D. A., Bibb, M. J., Chater, K. F. \& 7 other authors (1985). Genetic Manipulation of Streptomyces: a Laboratory Manual. Norwich: John Innes Foundation.

Inouye, M., Suzuki, H., Takada, Y., Muto, N., Horinouchi, S. \& Beppu, T. (1994). A gene encoding mycinamicin III O-methyltransferase from Micromonospora griseorubida. Gene 141, 121-124.

Kaluza, K., Hahn, M. \& Hennecke, H. (1985). Repeated sequences similar to insertion elements clustered around the nif region of the Rhizobium japonicum genome. J Bacteriol 162, 535-542.

Katz, L. \& Donadio, S. (1995). Macrolides. In Genetics and Biochemistry of Antibiotic Production, pp. 385-420. Edited by L. C. Vining \& C. Stuttard. Boston, MA: Butterworth-Heinemann.

Koplin, R., Wang, G., Hotte, B., Priefer, U. B. \& Puhler, A. (1993). A $3.9 \mathrm{~kb}$ DNA region of Xanthomonas campestris pv. campestris that is necessary for lipopolysaccharide production encodes a set of enzymes involved in the synthesis of dTDP-rhamnose. $J$ Bacteriol 175, 7786-7792. 
Kuhstoss, S., Huber, M., Turner, J. R., Paschal, J. W. \& Rao, R. N. (1996). Production of a novel polyketide through the construction of a hybrid polyketide synthase. Gene 183, 231-236.

Liu, H. W. \& Thorson, J. S. (1994). Pathways and mechanisms in the biogenesis of novel deoxysugars by bacteria. Annu Rev Microbiol 48, 223-256.

Lombo, F., Siems, K., Brana, A. F., Mendez, C., Bindseil, K. \& Salas, J. A. (1997). Cloning and insertional inactivation of Streptomyces argillaceus genes involved in the earliest steps of biosynthesis of the sugar moieties of the antitumour polyketide mithramycin. $J$ Bacteriol 179, 3354-3357.

MacNeil, D. J., Gewain, K. M., Ruby, C. L., Dezeny, G., Gibbons, P. H. \& MacNeil, T. (1992). Analysis of Streptomyces avermitilis genes required for avermectin biosynthesis utilizing a novel integration vector. Gene 111, 61-68.

Matsushima, P. \& Baltz, R. H. (1994). Transformation of Saccharopolyspora spinosa protoplasts with plasmid DNA modified in vitro to avoid host restriction. Microbiology 140, 139-143.

Mazodier, P., Petter, R. \& Thompson, C. (1989). Intergeneric conjugation between Escherichia coli and Streptomyces species. J Bacteriol 171, 3583-3585.

Olano, C., Rodriguez, A. M., Mendez, C. \& Salas, J. A. (1995). A second $\mathrm{ABC}$ transporter is involved in oleandomycin resistance and its secretion by Streptomyces antibioticus. Mol Microbiol 16, 333-343.

Roszkowski, J., Kotiuszko, D., Rafalski, A., Morawska, H. \& Raczynska-Bojanowska, K. (1972). Characteristics of mutants of Streptomyces noursei var. polifungini producing antibiotics. Acta Microbiol Pol B 4, 9-22.

Ruan, X., Pereda, A., Stassi, D. L. \& 8 other authors (1997). Acyltransferase domain substitutions in erythromycin polyketide synthase yield novel erythromycin derivatives. J Bacteriol 179, 6416-6425.

Sambrook, J., Fritsch, E. F. \& Maniatis, T. (1989).Molecular Cloning: a Laboratory Manual, 2nd edn. Cold Spring Harbor, NY: Cold Spring Harbor Laboratory.

Schwecke, T., Aparicio, J. F., Molnar, I. \& 10 other authors (1995).
The biosynthetic gene cluster for the polyketide immunosuppressant rapamycin. Proc Natl Acad Sci USA 92, 7839-7843.

Sezonov, G., Blanc, V., Bamas-Jacques, N., Friedmann, A., Pernodet, J.-L. \& Guerineau, M. (1997). Complete conversion of antibiotic precursor to pristinamycin IIA by overexpresion of Streptomyces pristinaespiralis biosynthetic genes. Nat Biotechnol 15, 349-355.

Solenberg, P. J., Matsushima, P., Stack, D. R., Wilkie, S. C., Thompson, R. C. \& Baltz, R. H. (1997). Production of hybrid glycopeptide antibiotics in vitro and in Streptomyces toyocaensis. Chem Biol 4, 195-202.

Tsukioka, Y., Yamashita, Y., Oho, T., Nakano, Y. \& Koga, T. (1997). Biological function of the dTDP-rhamnose synthesis pathway in Streptococcus mutans. J Bacteriol 179, 1126-1134.

Vara, J., Lewandowska-Skarbek, M., Wang, Y.-G., Donadio, S. \& Hutchinson, C. R. (1989). Cloning of genes governing the deoxysugar portion of the erythromycin biosynthesis pathway in Saccharopolyspora erythraea (Streptomyces erythraeus). J Bacteriol 171, 5872-5881.

Vogtli, M. \& Hutter, R. (1987). Characterisation of the hydroxystreptomycin phosphotransferase gene $(s p h)$ of Streptomyces glaucescens: nucleotide sequence and promoter analysis. Mol Gen Genet 208, 195-203.

Weber, J. M., Leung, J. O., Swanson, S. J., Idler, K. B. \& McAlpine, J. B. (1991). An erythromycin derivative produced by targeted gene disruption in Saccharopolyspora erythraea. Science 252, 114-117.

Wohlleben, W. \& Muth, G. (1993). Streptomyces plasmid vectors. In Plasmids, a Practical Approach, pp. 147-175. Edited by K. G. Hardy. Oxford, New York \& Tokyo: IRL Press.

Ylihonko, K., Tuikkanen, J., Jussila, S., Cong, L. \& Mantsala, P. (1996). A gene cluster involved in nogalamycin biosynthesis from Streptomyces nogalater: sequence analysis and complementation of early-block mutations in the anthracycline pathway. Mol Gen Genet 251, 113-120.

Received 10 November 1999; accepted 8 December 1999. 